ISSN 0258-7122

Bangladesh J. Agril. Res. 35(2) : 343-353, June 2010

\title{
COMPARATIVE STUDY ON YIELD AND YIELD ATTRIBUTES OF HYBRID, INBRED, AND NPT RICE GENOTYPES IN A TROPICAL IRRIGATED ECOSYSTEM
}

\author{
M. SiRAJUl ISLAM ${ }^{1}$, SHAOBING PENG ${ }^{2}$, ROMEO M. ViSPERAS ${ }^{2}$, M. SULTAN \\ UDDIN BHUIYA $^{3}$, S.M. ALTAF HOSSAIN ${ }^{3}$, AND A.W. JULFIQUAR ${ }^{1}$
}

\begin{abstract}
Yield potential of 16 rice genotypes including 12 hybrids, 3 inbreds, and I new plant type (NPT), were studied at the International Rice Research Institute farm under optimum crop management to achieve maximum attainable yields during the wet season (WS) of 2004 and dry season (DS) of 2005. Yield and yield components were determined at maturity. 1R76712H produced the highest grain yield (7.7 t/ha) followed by 1R75217H and Magat (7.6 t/ha) in WS; in DS, 1R79118H produced the highest grain yield $(9.17 \mathrm{t} / \mathrm{ha})$ followed by $1 \mathrm{R} 73855 \mathrm{H}$ (8.9 t/ha) and SL-8H (8.8 t/ha. The high yield of hybrid rice was due to high harvest index (0.50). Hybrid produced significantly higher productivity $(80.2$ $\mathrm{kg} / \mathrm{ha} / \mathrm{day}$ ) than inbred in DS, but the difference was not significant in WS. Hybrid produced higher spikelets/panicle and 1000-grain weight than inbred rice. Spikelet filling percent was higher in inbred than hybrid rice. The NPT rice genotype had the lowest spikelet filling percent, but the highest 1000-grain weight across the season.
\end{abstract}

Keywords : Yield, yield attributes, hybrid and inbred rice genotypes.

\section{Introduction}

Rice (Oryza sativa L.) has a special significance in Asia, where about $90 \%$ of the rice is produced and consumed as a staple food. Considering the increasing demand of rice due to population increase and decreasing land and water resources available for rice cultivation, it is critical to develop and use rice technologies that will result in higher yields (Virmani and Kumar, 2004). Experience in China and outside China clearly indicates that hybrid rice technology offers a viable option to meet this challenge. Hybrid rice varieties have clearly shown a 1-1.5 tha yield advantage over semi-dwarf inbred highyielding varieties in farmers' fields in China and other countries (Virmani and Kumar, 2004).

Higher yield of the hybrids was attributed to their increased dry plant weight and harvest index (Ponnuthurai et al., 1984). Increased HI of the hybrid rice

${ }^{1}$ Bangladesh Rice Research Institute (BARI), Gazipur 1701, Bangladesh, ${ }^{2}$ Crop and Environmental Sciences Division, International Rice Research Institute (IRRI), DAPO Box 7777, Metro Manila, Philippines, ${ }^{3}$ Bangladesh Agricultural University (BAU), Mymensingh 2202, Bangladesh. 
appeared to have resulted from their increased spikelet number and to some extent increased grain weight, which enhanced the sink capacity (Ponnuthurai et al., 1984).

Peng et al. (2003) reported that the average yield of $F_{1}$ hybrid rice was $17 \%$ and 4\% higher than that of indica inbreds in the 1998 wet season and 1999 dry season, respectively. Grain yield was highly and positively correlated to harvest index and the relationship between grain yield and biomass production was relatively weak. Therefore, the high grain yield was attributed to high harvest index and not to biomass at physiological maturity. The high harvest index of $F_{1}$ hybrids was due to the great amount of biomass that was accumulated before flowering and translocated to the grains during grain filling.

Utilization of heterosis by developing $F_{1}$ hybrid rice has been proved to be successful in increasing rice yield potential. The high yield in hybrid rice was due to the higher number of spikelets/panicle rather than the panicle number (Song, 1990a; Patnaik et al.. 1994). Development of new plant type (NPT) rice genotype was aimed at $30-50 \%$ higher yield potential than the existing semi-dwarf varieties in the tropical environments during the dry season (Peng et al., 1994). In view of the above discussions, the present study was undertaken to compare the yield and yield contributing characters of hybrid, inbred, and NPT rice genotypes in a tropical irrigated ecosystem.

\section{Materials and Method}

Experiments were conducted at the research farm of the International Rice Research Institute (IRRI), Los Baños $\left(14^{\circ} 1 l^{\prime} \mathrm{N}, 121^{\circ} 15^{\prime} \mathrm{E}, 21 \mathrm{~m}\right.$ altitude), Philippines during the wet season (WS) of 2004 and dry season (DS) of 2005. According to FAO taxonomy, the soil of the experimental site is Eutric Gleysols with a $\mathrm{pH}$ 6.6, $20.0 \mathrm{~g} / \mathrm{kg}$ organic C, $1.9 \mathrm{~g} / \mathrm{kg}$ total N, $14.5 \mathrm{mg} / \mathrm{kg}$ Olsen P, 1.3 meq $100 \mathrm{~g}$ extractable $\mathrm{K}$, and $37.2 \mathrm{meq} / 100 \mathrm{~g}$ cation exchange capacity.

Sixteen rice genotypes including 12 indica/ $F_{1}$ hybrids, three indica inbreds, and one new plant type (NPT) were arranged in a completely randomized block design with four replications in each of the 2004 WS and 2005 DS. The hybrids were not exactly the same across the two seasons. Among the hybrids, nine were developed by IRRI and four were developed by a private seed company. These four hybrids were SL-8H. SL-9H, SL-10H, and SL-11H. In 2005, DS, SL-8H, and BRRI DhanlH replaced SL-9H and SL-10H that were used in 2004 WS. BRRI DhanIH was developed by the Bangladesh Rice Research Institute. The two indica inbreds (1R72 and PSBRc28) were included because they were common check varieties in replicated yield trials in the IRRI breeding programme. A new indica inbred (lR72903-12l-2-l-2) and a NPT line (1R7296712-2-3) developed from tropical japonica was used in the experiment. 
Clean seeds of each genotype with at least $90 \%$ germination were soaked in water for 24 hours and incubated for another 24 hours. Then the pre-germinated seeds were sown in seedling tray filled with soil to produce uniform seedlings. Fourteen-day-old seedlings were transplanted on 2 July for 2004 WS and 20 January for 2005 DS at a hill spacing of $0.2 \times 0.2 \mathrm{~m}$ with four seedlings/hill. Plot size was $25 \mathrm{~m}^{2}$ in WS and $30 \mathrm{~m}^{2}$ in DS. Fifteen $\mathrm{kg} \mathrm{P} / \mathrm{ha}$ as single super phosphate, $20 \mathrm{~kg} \mathrm{~K} / \mathrm{ha}$ as KCI and $5 \mathrm{~kg} \mathrm{Zn/ha} \mathrm{as} \mathrm{zinc} \mathrm{sulfate} \mathrm{heptahydrate} \mathrm{were}$ applied as basal fertilizers in WS whereas, $30 \mathrm{~kg} P / \mathrm{ha}, 40 \mathrm{~kg} \mathrm{~K} / \mathrm{ha}$ and $5 \mathrm{~kg} \mathrm{Zn} / \mathrm{ha}$ were applied in DS. Basal fertilizers were applied and incorporated in all plots 1 day before transplanting. Nitrogen in the form of urea was split-applied: $30 \mathrm{~kg} / \mathrm{ha}$ at basal, $30 \mathrm{~kg} / \mathrm{ha}$ at mid-tillering, $30 \mathrm{~kg} / \mathrm{ha}$ at panicle initiation in WS; $60 \mathrm{~kg} / \mathrm{ha}$ at basal, $40 \mathrm{~kg} / \mathrm{ha}$ at mid-tillering, $60 \mathrm{~kg} / \mathrm{ha}$ at panicle initiation and $40 \mathrm{~kg} / \mathrm{ha}$ at flowering in DS. After transplanting, $5 \mathrm{~cm}$ water depth was maintained in the experimental plots. Ten days before harvest, the plots were drained to facilitate harvesting. Insects, diseases, and weeds were intensively controlled to avoid any yield loss.

Grain yield was determined from a $5 \mathrm{~m}^{2}$ sampling area from each plot and adjusted to $14 \%$ moisture content and expressed as $\mathrm{t} / \mathrm{ha}$. Grain moisture content was measured with a digital moisture meter (Steinlite, SL95, USA). Productivity per day was the grain yield over total growth duration. Above ground biomass was the total dry matter of straw, rachis and filled and unfilled spikelets. Harvest index was calculated as:

$\mathrm{HI}=(100 \times$ grain weight / above ground total biomass $)$.

At maturity, 12 hills were harvested diagonally from a $5 \mathrm{~m}^{2}$ area where grain yield was determined. Panicles were hand-threshed and the filled spikelets were separated from half-filled and empty spikelets by submerging them in tap water. Three sub-samples each of $30 \mathrm{~g}$ filled, $15 \mathrm{~g}$ half-filled and $2 \mathrm{~g}$ empty spikelets were taken for counting of the number of spikelets. The filled spikelets were then oven-dried at $70^{\circ} \mathrm{C}$ to a constant weight for determining 1000 -grain weight. Filled and half-filled spikelets were counted in an automatic counter (Electronic counter, Model 750, USA) and empty spikelets were counted manually. Spikelets/panicle and grain-filling percentage $(100 \times$ filled spikelet number/total spikelet number) was calculated.

Data were analyzed following analysis of variance using IRRISTAT (IRRI, 2005) and means of each genotype were compared based on Least Significant Difference (LSD) test at the 0.05 probability level. Three groups of tested genotypes were compared by three CONTRAST statements: inbred versus NPT, inbred versus hybrid, and NPT versus hybrid. 


\section{Results and Discussion Grain yield}

High grain yield was observed in 2004 WS with the average of $6.81 \mathrm{t} / \mathrm{ha}$ across 16 genotypes (Table 1). Seven genotypes produced more than $7 \mathrm{t} / \mathrm{ha}$ and six of them were hybrids developed by IRRI. 1R76712H produced the highest yield (7.66 t/ha) followed by lR752l7H (7.57 t/ha) and Magat (7.56 t/ha) in wet season. Seven genotypes produced more than $8 \mathrm{t} / \mathrm{ha}$ in 2005 DS and six of them were hybrids (Table 1$)$. The highest yield $(9.17 \mathrm{t} / \mathrm{ha})$ was produced by $1 \mathrm{R} 79118 \mathrm{H}$ followed by IR73855H, and SL-8H, which produced $8.88 \mathrm{t} / \mathrm{ha}$ and $8.78 \mathrm{t} / \mathrm{ha}$, respectively. The indica inbred, 1R72903-121-2-1-2, was the only non-hybrid that produced over $7 \mathrm{t} / \mathrm{ha}$. The hybrid BRRI hybrid dhanl developed by the Bangladesh Rice Research Institute produced a moderate yield of $7.56 \mathrm{t} / \mathrm{ha}$. Hybrids produced 15\% (1.1 t/ha) higher grain yield than the inbreds in DS, but the difference in WS was not significant. The NPT line produced statistically identical grain yield compared with the hybrids and inbreds in DS, but significantly lower yield in WS.

Maximum grain yield of inbred varieties was $6 \mathrm{t} / \mathrm{ha}$ in the wet season and $10 \mathrm{t} / \mathrm{ha}$ in the dry season in tropical irrigated rice systems under normal climatic conditions (Yoshida, 1981). Grain yield over 7 t/ha has been observed for hybrid rice in the wet season (Laza et al., 2004). In this study, six hybrids produced grain yield more than $7 \mathrm{t} / \mathrm{ha}$ in $2004 \mathrm{WS}$ with the highest grain yield of $7.66 \mathrm{t} / \mathrm{ha}$ from $1 \mathrm{R} 76712 \mathrm{H}$. The high yield of these hybrids was probably due to $10 \%$ higher daily total solar radiation $\left(18.2 \mathrm{Mi} \mathrm{m}^{-2} \mathrm{~d}^{-1}\right)$ and $65 \%$ higher sunshine hours (7.6/ha) in September 2004, which coincided with the ripening phase of these six hybrids, than the 25-year average from 1979 to 2003 (Table 3 and 4).

Grain yield in 2005 DS did not approach $10 \mathrm{t} / \mathrm{ha}$. Six hybrids produced grain yield over $8 \mathrm{t} / \mathrm{ha}$ and the maximum yield of $9.17 \mathrm{t} / \mathrm{ha}$ was produced by 1R79118H in 2005 DS. Average daily total solar radiation during the growing season in 2005 DS was about 10\% lower than the long-term average (Table 3 and 4). Therefore, less than 10 t/ha maximum yield in 2005 DS was due to limited total solar radiation.

Comparison among the inbreds, the NPT line and the hybrids showed that hybrids produced higher yield in both the seasons. Differences, however, between inbreds and hybrids were more pronounced in DS with 15\% higher yield. Hybrids also showed $20 \%$ and $7 \%$ higher yield over the NPT line during WS and DS, respectively. 
Table 1. Grain yield, harvest index, growth duration and productivity/day of 16 rice genotypes grown during 2004 wet season and 2005 dry season (Genotypes replaced in 2005 dry season are shown in parenthesis).

\begin{tabular}{|c|c|c|c|c|c|c|c|c|}
\hline & \multicolumn{2}{|c|}{ Grain yield (t/ha) } & \multicolumn{2}{|c|}{ Harvest index } & \multicolumn{2}{|c|}{$\begin{array}{c}\text { Growth duration } \\
\text { (days) }\end{array}$} & \multicolumn{2}{|c|}{$\begin{array}{c}\text { Productivity/day } \\
\text { (kg/ha/d) }\end{array}$} \\
\hline & $\begin{array}{l}2004 \\
\text { WS }\end{array}$ & $\begin{array}{l}2005 \\
\text { DS }\end{array}$ & $\begin{array}{l}2004 \\
\text { WS }\end{array}$ & $\begin{array}{c}2005 \\
\text { DS }\end{array}$ & $\begin{array}{c}2004 \\
\text { WS }\end{array}$ & $\begin{array}{c}2005 \\
\text { DS }\end{array}$ & $\begin{array}{c}2004 \\
\text { WS }\end{array}$ & $\begin{array}{c}2005 \\
\text { DS }\end{array}$ \\
\hline \multicolumn{9}{|l|}{ Inbred } \\
\hline IR72 & 6.84 & 6.91 & 0.45 & 0.45 & 112 & 117 & 61.1 & 67.1 \\
\hline PSBRc28 & 6.45 & 6.09 & 0.52 & 0.48 & 101 & 112 & 63.9 & 62.1 \\
\hline $\begin{array}{l}\text { 1R72903- } \\
\text { 121-2-1-2 }\end{array}$ & 7.08 & 8.34 & 0.42 & 0.43 & 125 & 126 & 56.6 & 74.5 \\
\hline Mean & 6.79 & 7.11 & 0.46 & 0.45 & - & - & 60.5 & 67.9 \\
\hline \multicolumn{9}{|l|}{ NPT } \\
\hline $\begin{array}{l}\text { 1R72967- } \\
12-2-3\end{array}$ & 5.73 & 7.69 & 0.39 & 0.44 & 125 & 125 & 45.8 & 69.3 \\
\hline \multicolumn{9}{|l|}{ Hybrid } \\
\hline Magat & 7.56 & 8.20 & 0.52 & 0.52 & 109 & 112 & 69.4 & 83.7 \\
\hline Mestizo & 6.08 & 8.23 & 0.42 & 0.46 & 119 & 125 & 51.1 & 74.2 \\
\hline 1R73 855 H & 6.93 & 8.88 & 0.48 & 0.53 & 102 & 112 & 67.9 & 90.6 \\
\hline 1R73868H & 7.33 & 8.72 & 0.52 & 0.53 & 109 & 112 & 67.2 & 89.0 \\
\hline 1R75217H & 7.57 & 7.88 & 0.50 & 0.52 & 109 & 112 & 69.4 & 80.4 \\
\hline 1R76712H & 7.66 & 7.61 & 0.52 & 0.51 & 109 & 112 & 70.3 & 77.6 \\
\hline 1R791 18H & 7.18 & 9.17 & 0.46 & 0.51 & 112 & 116 & 64.1 & 89.9 \\
\hline 1R79167H & 7.40 & 7.97 & 0.50 & 0.52 & 109 & 116 & 67.9 & 78.1 \\
\hline 1R79172H & 6.53 & 7.78 & 0.45 & 0.50 & 117 & 116 & 55.8 & 76.3 \\
\hline $\begin{array}{l}\text { SL-9H (BRRI } \\
\text { H dhanl) }\end{array}$ & 6.10 & 7.56 & 0.37 & 0.43 & 119 & 125 & 51.2 & 68.1 \\
\hline $\begin{array}{l}\text { SL-IOH (SL- } \\
8 \mathrm{H})\end{array}$ & 5.71 & 8.78 & 0.42 & 0.51 & 115 & 118 & 49.7 & 84.3 \\
\hline SL-IIH & 6.82 & 7.78 & 0.45 & 0.44 & 115 & 125 & 59.3 & 70.1 \\
\hline Mean & 6.90 & 8.21 & 0.47 & 0.50 & - & - & 61.9 & 80.2 \\
\hline LSD (0.05) & 0.55 & 0.90 & 0.03 & 0.03 & - & - & 4.9 & 8.6 \\
\hline CV (\%) & 5.7 & 7.9 & 3.8 & 4.0 & - & - & 5.7 & 7.8 \\
\hline Genotype & $* *$ & $* *$ & $* *$ & $* *$ & - & - & $* *$ & $* *$ \\
\hline $\begin{array}{l}\text { Inbred vs } \\
\text { NPT }\end{array}$ & $* *$ & ns & $* *$ & ns & - & - & $* *$ & ns \\
\hline $\begin{array}{l}\text { Inbred vs } \\
\text { Hybrid }\end{array}$ & ns & $* *$ & ns & $* *$ & - & - & ns & $* *$ \\
\hline $\begin{array}{l}\text { NPT vs } \\
\text { Hybrid }\end{array}$ & $* *$ & ns & $* *$ & $* *$ & - & - & $* *$ & $* *$ \\
\hline
\end{tabular}

* and ** Level of significance of $\mathrm{F}$ value at 0.05 and 0.01 probability levels, respectively, ns $=$ Not significant at $\mathrm{p}=0.05$. 
Table 2. Yield components of 16 rice genotypes grown during 2004 wet season and 2005 dry season (Genotypes replaced in 2005 dry season are shown in parenthesis).

\begin{tabular}{|c|c|c|c|c|c|c|c|c|}
\hline & \multicolumn{2}{|c|}{ Panicles/m ${ }^{-2}$} & \multicolumn{2}{|c|}{ Spikelets/panicle } & \multicolumn{2}{|c|}{$\begin{array}{l}\text { Spikelet filling } \\
\text { (\%) }\end{array}$} & \multicolumn{2}{|c|}{$\begin{array}{l}\text { 100-grain weight } \\
\text { (g) }\end{array}$} \\
\hline & $\begin{array}{l}2004 \\
\text { WS }\end{array}$ & $\begin{array}{l}2005 \\
\text { DS }\end{array}$ & $\begin{array}{l}2004 \\
\text { WS }\end{array}$ & $\begin{array}{l}2005 \\
\text { DS }\end{array}$ & $\begin{array}{l}2004 \\
\text { WS }\end{array}$ & $\begin{array}{l}2005 \\
\text { DS }\end{array}$ & $\begin{array}{c}2004 \\
\text { WS }\end{array}$ & $\begin{array}{l}2005 \\
\text { DS }\end{array}$ \\
\hline \multicolumn{9}{|l|}{ Inbred } \\
\hline IR72 & 401 & 488 & 79 & 76 & 84 & 85 & 23.5 & 22.8 \\
\hline PSBRc28 & 379 & 400 & 85 & 110 & 82 & 69 & 23.7 & 21.8 \\
\hline $\begin{array}{l}\text { 1R72903- } \\
121-2-1-2\end{array}$ & 334 & 383 & 102 & 109 & 78 & 79 & 24.4 & 24.2 \\
\hline Mean & 371 & 424 & 88 & 98 & 81 & 78 & 23.9 & 22.9 \\
\hline \multicolumn{9}{|l|}{ NPT } \\
\hline $\begin{array}{l}\text { 1R72967- } \\
12-2-3\end{array}$ & 300 & 345 & 115 & 108 & 59 & 67 & 28.4 & 27.7 \\
\hline \multicolumn{9}{|l|}{ Hybrid } \\
\hline Magat & 410 & 452 & 99 & 97 & 76 & 77 & 23.5 & 23.0 \\
\hline Mestizo & 319 & 360 & 99 & 102 & 73 & 83 & 27.5 & 26.0 \\
\hline 1R73 $855 \mathrm{H}$ & 365 & 455 & 107 & 97 & 67 & 76 & 24.7 & 24.1 \\
\hline 1R73868H & 330 & 394 & 110 & 122 & 77 & 73 & 24.5 & 24.4 \\
\hline 1R75217H & 360 & 427 & 109 & 112 & 77 & 74 & 23.8 & 23.3 \\
\hline 1R76712H & 341 & 395 & 117 & 107 & 75 & 76 & 25.2 & 23.7 \\
\hline 1R791 18H & 339 & 351 & 108 & 125 & 71 & 79 & 25.3 & 25.4 \\
\hline 1R79167H & 359 & 436 & 106 & 106 & 77 & 75 & 22.8 & 22.1 \\
\hline 1R79172H & 375 & 380 & 99 & 104 & 80 & 85 & 23.2 & 23.4 \\
\hline $\begin{array}{l}\text { SL-9H } \\
\text { (BRRI H } \\
\text { dhanl) }\end{array}$ & 281 & 380 & 142 & 115 & 54 & 69 & 26.4 & 24.6 \\
\hline $\begin{array}{l}\text { SL-1OH } \\
\text { (SL-8H) }\end{array}$ & 263 & 341 & 123 & 124 & 70 & 80 & 25.3 & 26.3 \\
\hline SL-IIH & 250 & 323 & 135 & 123 & 72 & 76 & 26.8 & 25.4 \\
\hline Mean & 333 & 391 & 113 & 111 & 72 & 77 & 24.9 & 24.3 \\
\hline $\operatorname{LSD}_{(0.05)}$ & 24 & 54 & 9 & 18 & 5 & 6 & 0.27 & 0.67 \\
\hline CV (\%) & 5 & 10 & 6 & 12 & 5 & 5 & 0.8 & 1.9 \\
\hline Genotype & $* *$ & $* *$ & $* *$ & $* *$ & $* *$ & $* *$ & $* *$ & $* *$ \\
\hline $\begin{array}{l}\text { Inbred vs } \\
\text { NPT }\end{array}$ & $* *$ & $* *$ & $* *$ & ns & $* *$ & $* *$ & $* *$ & $* *$ \\
\hline $\begin{array}{l}\text { Inbred vs } \\
\text { Hybrid }\end{array}$ & $* *$ & $* *$ & $* *$ & $* *$ & $* *$ & ns & $* *$ & $* *$ \\
\hline $\begin{array}{l}\text { NPT vs } \\
\text { Hybrid }\end{array}$ & $* *$ & $*$ & ns & ns & $* *$ & $* *$ & $* *$ & $* *$ \\
\hline
\end{tabular}

* and ** Level of significance of $\mathrm{F}$ value at 0.05 and 0.01 probability levels. respectively. ns $=$ Not significant at $\mathrm{p}=0.05$. 


\section{Harvest index}

Harvest index varied significantly among the genotypes in both 2004 WS and 2005 DS (Table 1). Three highest yielding genotypes gave a harvest index of $0.50-0.52$ in 2004 WS. All SL hybrids developed by a private seed company and the NPT line gave lower harvest index with the lowest in SL-9H in WS. Hybrids developed by IRRI showed high harvest index-equal or greater than 0.50 except Mestizo in DS. Compared to the hybrids, the inbreds had lower HI in DS, but the difference was not significant in the WS.

Table 3. Long-term monthly means of weather data recorded from 1979 to 2003 at the wetland site weather station of IRRI, Los Baños, the Philippines.

\begin{tabular}{|c|c|c|c|c|c|c|c|}
\hline \multirow{2}{*}{$1979-2003$} & \multicolumn{3}{|c|}{ Temperature $\left({ }^{0} \mathrm{C}\right)$} & \multirow{2}{*}{$\begin{array}{c}\text { Rainfall } \\
(\mathrm{mm})\end{array}$} & \multirow{2}{*}{$\begin{array}{c}\text { Radiation } \\
\left(\mathrm{MJ} \mathrm{m}^{-2} \mathrm{~d}^{-1}\right)\end{array}$} & \multirow{2}{*}{$\begin{array}{l}\text { Sunshine } \\
\left(\mathrm{hr} \mathrm{d}^{-1}\right)\end{array}$} & \multirow{2}{*}{$\begin{array}{c}\text { Relative } \\
\text { humidity (\% }\end{array}$} \\
\hline & Max & Min & Average & & & & \\
\hline January & 28.3 & 21.3 & 25.1 & 40.6 & 14.1 & 5.5 & 84 \\
\hline February & 29.1 & 21.8 & 25.5 & 25.8 & 17.4 & 7.2 & 83 \\
\hline March & 30.3 & 22.5 & 26.4 & 39.7 & 20.3 & 8.1 & 81 \\
\hline April & 32.3 & 23.7 & 28.0 & 41.6 & 22.0 & 8.9 & 79 \\
\hline May & 33.0 & 24.5 & 28.7 & 142.1 & 20.1 & 7.6 & 79 \\
\hline June & 32.2 & 24.5 & 28.3 & 234.8 & 18.0 & 6.0 & 82 \\
\hline July & 31.3 & 24.1 & 27.7 & 313.2 & 16.7 & 5.1 & 84 \\
\hline August & 31.1 & 24.2 & 27.7 & 230.8 & 16.1 & 4.8 & 85 \\
\hline September & 31.1 & 24.0 & 27.6 & 233.8 & 16.6 & 4.6 & 86 \\
\hline October & 30.6 & 23.8 & 27.2 & 320.7 & 15.1 & 5.1 & 85 \\
\hline November & 29.8 & 23.5 & 26.6 & 232.7 & 13.6 & 5.2 & 85 \\
\hline December & 28.4 & 22.6 & 25.5 & 158.4 & 12.4 & 4.5 & 85 \\
\hline
\end{tabular}

The ultimate partitioning of dry matter between grain and vegetative parts is indicated by the grain-to-straw ratio or harvest index (HI). It is one of the yield determining factors. The partitioning of dry matter to grain and straw varied among the genotypes. Fageria et al. (1997) reported that HI of improved semidwarf indica varieties ranged between 0.45 and 0.55 . In this study, the hybrids had higher HI than inbreds because of their better physiological efficiency. The development of NPT with large panicles, few tillers and sturdy stems using tropical japonica germplasm was aimed at improving rice yield potential (Peng et al., 1994). However, the grain yield of the NPT line was the lowest due to their low HI. This result is consistent with the report of Laza et al. (2003) that the NPT line produced the lowest grain yield due to low HI. The growth season also influenced HI. In the wet season, HI is generally lower due to low irradiance and higher temperature (De Datta et al., 1981). 


\section{Growth duration and productivity per day}

The growth duration of the 16 genotypes varied from 101 to 125 days in 2004 WS and 112 to 125 days in 2005 DS (Table 1). The high yielding genotypes did not necessarily have longer growth duration. The variation in growth duration among the 16 genotypes was shorter in 2005 DS than 2004 WS.

Significant variation in productivity per day $(\mathrm{kg} / \mathrm{ha} / \mathrm{d})$ was observed among the tested genotypes (Table 1). The highest yielding genotypes 1R76712H, $1 \mathrm{R} 75217 \mathrm{H}$, and Magat in WS produced around $70 \mathrm{~kg} / \mathrm{ha} / \mathrm{d}$. Whereas in the DS, the highest yielding genotypes 1R79118H, 1R73855, and SL-8H produced around $90 \mathrm{~kg} / \mathrm{ha} / \mathrm{d}$. In the DS, the highest productivity per day was 28 percent higher compared to the WS. Generally, the highest yielding genotypes also showed higher productivity per day in hybrid rice in both the WS, and the DS. No significant variation in daily productivity was observed between hybrids and inbreds in the WS, but the difference was significant in the DS. Besides grain yield (t/ha), productivity per day ( $\mathrm{kg} / \mathrm{ha} / \mathrm{d})$ is also important for comparing genotypes (Yuan, 2002). Usually varieties with longer growth duration produce more yield than the varieties with shorter growth duration. Daily productivity may be a better criterion for comparing varietal performance. In the present study, hybrids showed significantly higher daily productivity than inbreds and the NPT line in the DS.

\section{Panicles per $\mathbf{m}^{2}$}

Yield components measured in 2004 WS and 2005 DS are presented in Table 2. Panicles $/ \mathrm{m}^{2}$ varied significantly among the tested genotypes in both the seasons. Among the inbred rice, 1R72 produced the highest panicles $/ \mathrm{m}^{2}$ in both the seasons. Whereas, hybrid Magat produced the highest panicles $/ \mathrm{m}^{2}$ in both seasons. On an average, inbred rice genotypes produced $11 \%$ and $8 \%$ more panicles $/ \mathrm{m}^{2}$ than the hybrids in 2004 WS and 2005 DS, respectively. The NPT line produced the lowest panicles $/ \mathrm{m}^{2}$ in both the seasons.

The major yield components in rice are number of panicles per unit area, number of spikelets/panicle, spikelet filling percentage and individual grain weight normally expressed as 1000-grain weight. Hybrids produced lower panicles $/ \mathrm{m}^{2}$ compared to inbred rice which indicates that the high yield of hybrid rice might be due to higher spikelets/panicle, spikelet filling percentage and grain weight. Ponnuthurai et al. (1984) and Virmani et al. (1981) reported that hybrids had lower number of panicles $/ \mathrm{m}^{2}$.

\section{Spikelets per panicle}

Distinct genotypic variation was observed in spikelets/panicle in both 2004 WS and 2005 DS (Table 2). 1R72 had the lowest spikelets/panicle in both the 
seasons. Difference in spikelets/panicle between hybrid and inbred was significant in both the seasons, but the difference between the hybrids and the NPT line was not significant. Hybrids had $27 \%$ and $13 \%$ higher spikelets/panicle in WS and DS, respectively.

Table 4. Monthly means of weather data recorded during experiment (from 2004 wet season to 2005 dry season) at the wetland site weather station of IRRI, Los Baõos, the Philippines.

\begin{tabular}{|c|c|c|c|c|c|c|c|}
\hline \multirow{2}{*}{$\begin{array}{l}\text { Year/ month } \\
2004\end{array}$} & \multicolumn{3}{|c|}{ Temperature $\left({ }^{0} \mathrm{C}\right)$} & \multirow{2}{*}{$\begin{array}{c}\text { Rainfall } \\
(\mathrm{mm})\end{array}$} & \multirow{2}{*}{$\begin{array}{c}\text { Radiation } \\
\left(\mathrm{MJ} \mathrm{m}^{-2} \mathrm{~d}^{-1}\right)\end{array}$} & \multirow{2}{*}{$\begin{array}{c}\text { Sunshine } \\
\left(\mathrm{hr} \mathrm{d}^{-1}\right)\end{array}$} & \multirow{2}{*}{$\begin{array}{c}\text { Relative } \\
\text { humidity (\%) }\end{array}$} \\
\hline & Max & Min & Average & & & & \\
\hline June & 31.2 & 25.0 & 28.1 & 260.0 & 14.2 & 4.9 & 82 \\
\hline July & 31.7 & 24.5 & 28.1 & 370.0 & 16.9 & 6.6 & 85 \\
\hline August & 31.0 & 25.0 & 28.0 & 232.2 & 13.8 & 4.6 & 86 \\
\hline September & 32.1 & 23.9 & 28.0 & 105.4 & 18.2 & 7.6 & 85 \\
\hline October & 30.7 & 23.4 & 27.1 & 152.7 & 15.4 & 6.0 & 87 \\
\hline November & 29.2 & 24.1 & 26.6 & 340.3 & 11.3 & 4.4 & 88 \\
\hline December & 28.6 & 23.4 & 26.0 & 58.6 & 12.4 & 5.3 & 84 \\
\hline \multicolumn{8}{|l|}{2005} \\
\hline January & 28.2 & 22.0 & 25.1 & 17.1 & 13.5 & 5.6 & 88 \\
\hline February & 30.0 & 22.3 & 26.2 & 16.8 & 17.7 & 8.3 & 86 \\
\hline March & 29.9 & 22.9 & 26.4 & 54 & 16.8 & 7.3 & 86 \\
\hline April & 32.3 & 23.5 & 27.9 & 58.2 & 20.5 & 9.4 & 82 \\
\hline May & 34.2 & 25.0 & 29.6 & 51.1 & 19.3 & 8.5 & 80 \\
\hline June & 32.8 & 25.2 & 29.0 & 85.7 & 16.7 & 6.4 & 85 \\
\hline
\end{tabular}

\section{Spikelet filling percentage}

Spikelet filling percentage varied among the genotypes and was found better in inbred rice (Table 2). Significantly higher spikelet filling was observed in inbred rice than in the hybrids and the NPT line in 2004 WS, but the difference between hybrid and inbred rice was not significant in 2005 DS. The NPT line showed the lowest spikelet filling in both the seasons. Cultivars with small panicle size such as $1 \mathrm{R} 72$ generally filled well, whereas hybrids with large panicle size (SL-9H, SL-101-1, SL-I IH and NPT line) filled poorly.

\section{0-grain weight}

The 1000-grain weight of the tested genotypes remained relatively stable across seasons and hybrids produced higher grain weight than the inbreds, where NPT produced the highest grain weight across seasons (Table 2). This supports the statement that 1000-grain weight is a stable genetic character in rice (Yoshida, 1981). 
Analysis of yield components indicated that greater sink size and higher grain weight contributed to the higher grain yield in hybrid rice. The greater sink size of hybrids was the result of a higher number of spikelets/panicle rather than panicle number (Virmani et al., 1981; Ponnuthurai et al., 1984; Song et al., 1990b; Patnaik et al., 1994). The lower grain yield in the NPT was due to fewer panicle number and poor grain filling percentage in spite of greater sink size and higher grain weight. Hybrids also had lower grain filling percentage than inbreds. The higher grain filling percentage of inbred rice may be related to their smaller panicle size compared to hybrid rice. According to Ying et al. (1998), the internal competition for carbohydrates during grain filling period is high when there is a large sink size leading to poor grain filling. This contradicts with the reports of Yan (1988) and Song et al. (1990b) which states that hybrids had a higher grain filling percentage in spite of their large panicle size.

In summary, hybrid rice produced higher grain yield than inbred and NPT line genotype in both the seasons and these difference was more prominent in DS than WS. Hybrid 1R76712H produced the highest grain yield (7.66 t/ha) in wet season and IR79I18H produced the highest grain yield (9.17 t/ha) in dry season. Like grain yield, hybrid rice also produced higher productivity/day than inbred and NPT rice. The high yield of hybrid rice was due to the high harvest index. Hybrid rice produced lower panicles $/ \mathrm{m}^{-2}$ than inbred rice whereas, the NPT line produced the lowest paniles $/ \mathrm{m}^{2}$. The high yield of hybrid rice was also due to high spikelets/panicle and high individual grain weight. The low yield of NPT line was due to low panicles $/ \mathrm{m}^{2}$ and also low spikelet filling percentage in spite of its high individual grain weight.

\section{Acknowledgements}

This study was a part of the Ph.D thesis research of the senior author. We gratefully acknowledge the financial support of Department for International Development (DFID), UK through the International Rice Research Institute (IRRI) - Poverty Elimination Through Rice Research Assistance (PETRRA) Project of Bangladesh which enabled the senior author to conduct Ph.D thesis research at IRRI, Los Banos, Philippines.

\section{References}

De Datta, S.K., P.J. Stangel and E.T. Craswell. 1981. Evaluation of nitrogen fertility and increase fertilizer efficiency in wetland rice soils. In: Proceedings of symposium on paddy soil. Inst. of soil sci. Academia Sinica Sci. Press, Beijing. Springer-Verlag Berlin, Heidelberg, New York. pp. 171-206.

Fageria, N.K., V.C. Baligar and C.A. Jones. 1997. Rice. In: Growth and mineral nutrition of field crops. Marcel Dekker, Inc. New York, Basel, Hong Kong. pp. 283-343.

IRRI (International Rice Research Institute). 2005. IRRISTAT for Windows. Version 5, Los Baños, Philippines. 356p. 
Laza, M.R.C., S. Peng, S. Akita and H. Saka. 2003. Contribution of biomass portioning and translocation to grain yield under sub-optimum growing condition in irrigated rice. Plant Prod. Sci. 6(1): 28-35.

Laza, M.R.C., S. Peng, S. Akita and H. Saka. 2004. Effect of panicle size on grain yield of IRRIreleased indica rice cultivars in the wet season. Plant Prod. Sci. 7(3): 271-276.

Patnaik, R.N., K. Pande and P.J. Jachuck. 1994. Effect of different levels of nitrogen fertilizer on growth rate at maturity (GRM) and yield of rice hybrids. Crop Res. 8(2): 207-2 12.

Peng, S., G.S. Khush and K.G. Cassman. 1994. Evolution of the new plant ideotype for increased yield potential. In: Cassman, K.G., (ed.) Breaking the Yield Barrier. Intl. Rice Res. Inst., Manila, Philippines. pp. 5-20.

Peng, S., J. Yang, R.C. Laza, A.L. Sanico, R.M. Visperas and T.T. Song. 2003. Physiological bases of heterosis and crop management strategies for hybrid rice in the tropics. In: Virmani, S.S., C.X. Mao and B. Dardy (eds.) Hybrid Rice for Food Security, Poverty Alleviation, and Environment Protection. Proc. 4th Intl. Symp. Hybrid Rice, 14-17 May 2002, Hanoi, Vietnam. Los Baños (Philippines): Intl. Rice Res. Inst. pp. 153-170.

Ponnuthurai, S., S.S. Virmani and B.S. Vergara. 1984. Comparative studies on the growth and grain yield of some $\mathrm{F}_{1}$ rice (Oryza sativa L.) hybrids. Philip. J. Crop Sci. 9(3): 183-193.

Song, X., W. Agata and Y. Kawamitsu. 1990a. Studies on dry matter and grain production of $\mathrm{F}_{1}$ hybrid rice in China. I. Characteristics of dry matter production. Jpn. J. Crop Sci. 59(1): 19-28.

Song, X., W. Agata and Y. Kawamitsu. 1990b. Studies on dry matter and grain production of $\mathrm{F}_{1}$ hybrid rice in China. II. Characteristics of grain production. Jpn. J. Crop Sci. 59(1): 29- 33.

Virmani, S.S., R.C. Chaudhary and G.S. Khush. 1981. Current outlook on hybrid rice. Oryza. 18: 67-84.

Virmani, S.S. and I. Kumar. 2004. Development and use of hybrid rice technology to increase rice productivity in the tropics. Intl. Rice Res. Notes. 29(1): 10-19.

Yan, Z. 1988. Agronomic management of rice hybrids compared with conventional varieties. In: Hybrid Rice. Manila (Philippines): Intl. Rice Res. Inst. pp. 217-224.

Ying J., S. Peng, Q.R. He, H. Yang, C.D. Yang, R.M. Visperas and K.G. Cassman. 1998. Comparison of high-yield rice in tropical and subtropical environments. I. Determinants of grain and dry matter yields. Field Crops Res. 57(1): 71-84.

Yoshida, S. 1981. Fundamentals of Rice Crop Science. Intl. Rice Res. Inst., Los Baños, Leguna, Philippines. 269 p.

Yuan, L.P. 2002. Personal communication. In: International hybrid rice cultural management training course. China National Hybrid Rice Research and Development Center. Changsha, China. 158p. 